\title{
SOCIAL NETWORK TYPES AMONG POLISH SENIOR CITIZENS AND PERCEPTION OF THE QUALITY OF THEIR LIVES
}

\author{
Agnieszka Kozerska \\ Jan Dlugosz University in Czestochowa, Poland
}

\begin{abstract}
The objective of this paper is to establish social network typologies of Polish elderly people based on empirical data. Moreover, the aim is to determine the frequency of occurrence of particular network types in Poland and examine the association between the distinguished social network types and older people's perceptions of the quality of their lives. The analysis was conducted using data collected in 2013 and is available on www. diagnoza.com. The data concerns 9673 Polish senior citizens. The cluster analysis was used to form groups of people participating in the analysis. The following three types of social networks among Polish seniors were identified: "diverse", "family and friends" as well as "restricted". The restricted type constitutes the most numerous group but it is characterized by the lowest level of well-being. However, the elderly belonging to the diverse network are found to be the most satisfied with the quality of their lives.
\end{abstract}

Keywords: informal learning of seniors; senior citizens; social networks.

\section{Introduction}

A social network is a social structure made up of individuals with whom one maintains contacts. The social network consists of immediate and distant family as well as non-relatives one encounters in different situations and circumstances. Social networks provide social support to their members facing various problems and challenges. The more an individual establishes close relationships the more likely it is that an individual can receive support. Social networks are an essential component of social capital which can be defined as: "social networks seem to be regulated by moral norms and customs (and not, or not only, by formal legal regulations) binding an individual to society in order to enable them to cooperate with other members of society for the benefit of the common good" (Czapiński, 2011, p.284). Older people's social networks can be analyzed taking their extent into account (a number of people composing social networks), their structure (members of social networks and their sense of belonging to various categories, such as family, friendship, a circle of acquaintances) and their significance in people's lives (Grotowska-Leder, 2008). For the purposes of this article, the extent and structure of social networks were taken into consideration when conducting the analyses.

Analyzing social participation of older people may be interesting not only from the standpoint of gerontology, but also social assistance policy (Wenger, 1991). Furthermore, it is extremely important to know social network types 
among the elderly in order to identify their needs and determine methods of helping those in need and estimate social exclusion risks. The effectiveness of the support provided to senior citizens in difficult situations may depend on a social network type, its structure and extent. Members of the social network may help an individual to acquire information which may make it easier for them to overcome difficulties and challenges in their lives (Wenger, 1991). The social network plays a crucial role in adapting to new living conditions, for example, death of a spouse. Participation in the social network may be educational in nature and related to different types of seniors' informal education. Local, social and family environment of the elderly can be regarded as an element of educational environment (Kozerska, 2013). When interacting with others, an individual gains knowledge in various areas of social life. Observations focused on people's behaviours, their way of thinking and acting as well as comparisons with their own behaviours stimulate reflection and encourage them to acquire knowledge. People learn through community participation, active involvement in society (Wenger, 1998). "The process of learning is located in the interface of people's biography and sociocultural environment in which they live, for it is at this intersection that experiences occur (...) Learning occurs in a tension field between the individual and the society" (Illeris, 2006, p. 131). In interpersonal interactions, various types of psychosocial processes, which in a sense shape and change an individual's identity, take place in an individual's life influencing their personality (Kargul, 2005). Interpersonal relationships "are the field of education in which an individual can learn the skill of empathic communication, provided that an individual can make an educational effort to learn communication codes of an interaction partner (...) Intuition plays a significant role in the educational process defined in this way" (Kargul, 2005). According to Lukaszewski (1986), an individual's personality structure changes during interactions with the outside world. There is scientific evidence that senior citizens, who interact with many people, belonging to extended social networks are likely to assess their own well-being as relatively high compared to people belonging to less extended social networks (Litwin \& Stoeckel, 2013, Dominguez, S. \& Arford, T., 2010, Garcia et al., 2005).

\section{Social network typologies among elderly people and their representation in selected countries}

Social network types among older adults depend on the cultural contest. The authors (Litwin \& Stoeckel, 2013) note that there are four types of social networks that were identified by analyses of data gathered in different countries. The authors distinguished a typology of four network types that were labelled: $a /$ diverse, b/family-focused, c/ friend-focused, $d /$ restricted. The presence of a particular network type depends on the country where research was conducted. It should be noted, however, that Litwin and Stoeckel state that unique types of 
social networks, which are specific to a particular area, can be found in source literature, for example, the widowed network in Mexico (Doubova et al., 2010), or the distant family network type in Hong Kong (Cheng et al., 2009). The analysis of trust network types based on the SHARE data concerning Europe's ageing population (Litwin \& Stoeckel, 2013) leads to the conclusion that the spouse and children network has emerged as the dominant social network in Southern European countries, whereas the children network type has become prevailing in Western Europe. In this respect, Polish seniors are similar to elderly people in Southern Europe who prefer the spouse and children trust network (34,7\%). Furthermore, Polish elderly population is characterized by relatively considerable popularity of the spouse type (26,7\%). When comparing the strength of family ties in different countries around the world (Alesina \& Giuliano, 2010), it can be stated that Poland holds one of the highest positions in the world. Network types mainly oriented towards non-family members appear to be relatively unknown in Poland. For instance, Polish senior citizens are not willing to belong to trust network types such as friend (4\%) and other $(3,7 \%)$. Similar results were found by Kääriäinen and Lehtonen (2006). The analyses carried out by the authors reveal that seniors' social networks consisting mainly of family members and very close friends were the most popular type among post-socialist countries. Social networks composed of non-family members tended to dominate in Nordic countries (e.g. Denmark and Norway), as well as in Great Britain, the USA, Australia, Canada. The popularity of social network models made up of non-family members among elderly people in Poland may be related to a low level of social trust after the 1989 political transformation in Poland. Polish older adults lived most of their lives in a totalitarian country. Even though Poland has been a democratic country for over 20 years, it seems difficult to change habits. According to the analyses carried out by Growiec (2009), social trust plays a substantial role in the formation of social networks composed of acquaintances (non-relatives constituting a group distinct from the "friends" group). Social trust increases a circle of people with whom one can maintain social relationships. A similar connection can be noticed between of social trust and building relationships with friends. However, there seems to be no link between social trust and establishing family ties. Therefore, social trust is needed to build extended social networks including not only family members.

The type and nature of social participation of older people are related to variables such as (Dzięgielewska, 2006): gender (women are more actively engaged in society compared to men), education (the higher the education level, the higher the level of social participation), health condition, features of family environment such as having children and grandchildren, family economic conditions (the better ones the higher the level of participation), the place of residence (there are more offers for elderly urban dwellers which results in increasing social participation). The research on social networks shows that people who experience loneliness often tend to be linked to others who are 
lonely (Cacioppo et al., 2009). Moreover, longitudinal research (Cacioppo et al., 2009) suggests that people who are around lonely individuals tend to grow lonelier over time. Loneliness spreads much more easily among women than among men. Social participation is an important correlate of well-being. The research conducted so far has found that different social network types have significant effects on an elderly individual's mental health and the quality of their life.

\section{Research results on a relationship between social networks among seniors and their well-being}

Research conducted in Israel identified a typology of five social networks among older people: diverse, friends focused, neighbour focused, family focused and restricted (Litwin, 2001). High income, higher level of education and good health condition are observed among the elderly embedded in the diverse network type (30\% of the polled). For comparison, the friends focused type can be described similarly, with a slight difference - the "friends" network $(23,7 \%)$ is composed of relatively younger people. Low-income individuals with low levels of education belong to the "family" type (9\%). Five network types, similar to the ones discussed above, were derived in the USA based on other research carried out among the elderly: diverse, family, friends and non-family-restricted, non-friends (Fiori et al., 2006). The diverse network, which accounts for $32 \%$ of the population, is the most common type among American older people, whereas the family type (12\%) appears to be the least numerous group. The analysis of the association between the social network type and mental health shows that depressive symptomatology was the highest for individuals in the non-friends network and lowest for individuals in the diverse type. Results indicate that the social network type has a powerful impact on mental health among senior citizens. The results suggest that the absence of family in the context of having friends is less detrimental than the absence of friends in the context of having family. Further research (Litwin \& Shiovitz-Ezra, 2010) on older Americans revealed five social network types: diverse, friend, congregant, family and restricted. The friend network (30\% of the polled) appears to be the most prevalent. This network type is characterized by maintaining close ties and contacts with many friends as well as the frequency of attendance in organized group meetings. For comparison, the family type (15\%) consists of the least number of members and it is characterized by a large number of children and involves a limited number of social ties with friends. Litwin and Shiovitz-Ezra's research shows statistically significant association between a social network type and each of well-being indicators analyzed by the researchers. Respondents embedded in the network types characterized by greater social capital tended to exhibit better well-being in terms of greater happiness, less anxiety and less loneliness. Similar conclusions were formulated by Litwin and Stoeckel (2013) 
on the basis of data concerning elderly people in Europe. They noticed that trust networks consisting mainly (or only) of a spouse are not associated with a sense of well-being, although they are correlated with emotional closeness.

Adams and Blieszner (1995) claim that elderly individuals who build a large social circle of friends and have close ties and contacts with their families are more socially and psychologically adjusted than those who do not maintain close family ties. Based on the literature review, Adams and Blieszner (1995) stated that instrumental support is more often provided by family, whereas friends are more likely to provide emotional support. Family members typically provide assistance to older adults when long-term support is needed. This assistance can meet a variety of needs e.g. personal hygiene, household chores, transportation. Social networks made up of close and distant friends are more essential for mental well-being of elderly people than social networks composed mainly of family members and relatives. Older people's friends are often their peers of same or similar age which may be important when providing emotional support. Since they are of similar age, they have similar life experiences. Adams and Blieszner emphasize that interactions with friends and satisfaction with friend interactions are key predictors of happiness. Moreover, they note that relationships with relatives have a significant impact on a sense of happiness.

\section{Purpose}

The objective of this paper is to establish social network typologies of Polish elderly people based on empirical data. Moreover, the aim is to determine the frequency of occurrence of particular network types in Poland and examine the association between the distinguished social network types and older people's perceptions of the quality of their lives. The following questions were asked:

What social network types do seniors tend to belong to?

What is the relationship between preferred social network types and seniors' subjective quality of life?

Data made available in the framework of the Diagnoza Spoteczna project (the Social Diagnosis project) [www.diagnoza.com] has been analyzed in order to answer the questions. The objective of the project is a diagnosis of the conditions and quality of life among the Poles. The research is regularly conducted (at intervals of several years) on a random sample of the Poles and is based on a panel forum. Seven rounds of research have been carried out so far: in 2000, 2003, 2005, 2007, 2009, 2011, 2013. "The results of the Social Diagnosis project reveal not only the current state of Polish society, but also allow us to follow how it has changed over the last ten years. Furthermore, taking into account earlier research on the quality of life in Poland, it even gives us an insight into nearly the entire process of system transformation" ${ }^{\text {. Diagnoza }}$

3 http://www.diagnoza.com/ 
Spleczna is public in nature and a database collected during the research can be downloaded free of charge from the website: www.diagnoza.com.

\section{Data}

The data concerning Polish seniors (people above the age of sixty) was collected via a survey in 2013 and used for the purpose of analysis. In a randomly chosen research sample including 9673 persons, there were 5586 women and 4087 men. Cases with missing data were omitted. Complete data were obtained from 8093 people. The respondents were divided into three subgroups differing in social contacts net. The method of statistical analysis which was used to group the polled is a cluster analysis - grouping with the use of k-means method. This method is used to reveal the structures of data. Its purpose is to divide the polled seniors into groups in a way that people belonging to the same groups were as much similar to each other and at the same time the least similar to those belonging to other groups. Variables taken into consideration during grouping are numbers of persons whom a senior regularly stays in touch with for the social and personal purposes: 1 . The family, 2. Close friends, 3. Acquaintances (colleagues, neighbours, others).

\section{Results}

There have been differentiated the following types of social networks in which Polish seniors are functioning as a result of the cluster analysis:

Type 1: family and friends Group1, includes 2211 persons, that is $27,3 \%$ of all the polled people at the age of $60+(\mathrm{N}=8093)$. Every third polled senior functions in this social network type. These are people who are regularly in social and personal contacts with family members (an average number of people whom they stay in touch with $M=13,2)$. Moreover, the social network of seniors includes also good friends $(\mathrm{M}=7,1)$ and friends with whom they stay in touch $(\mathrm{M}=7,6)$.

In the group family and friends $70 \%$ of respondents are married. The average age is $\mathrm{M}=69$ years; standard deviation is $\mathrm{s}=7,6$. The average number of years of formal education is $10,8, \mathrm{~s}=3,4.6 \%$ of seniors functioning in the family and friends network type are participants of a religious organization, and $1,2 \%$ participate in activities of organizations promoting knowledge (for example, TAU). When asked about a membership in organizations, associations, parties, committees, councils or religious groups $20,8 \%$ of respondents answered positively. In group 1 there are socially active persons, a relatively small proportion has the feeling of loneliness. $14 \%$ of seniors from this group claim that they feel lonely, even though they do not want that. Almost all persons from this group (95\%) feel loved and being confided in.

Type 2 resrticted: Group 2 includes 5623 persons, $69,5 \%$ of all the polled $(\mathrm{N}=8093)$, who are regularly in social and personal contacts mainly with a small 
number of family members. In comparison with the other groups they have a small number of friends and family members with whom they stay in touch. They are regularly in contact with 5 family members on average, 2 good friends $(M=2,6)$ and about three acquaintances $(M=2,7)$. This is the most frequent social network type in which Polish seniors function. In this group 57,9\% of seniors are married. The average age is $\mathrm{M}=70,7 ; \mathrm{s}=8,3$.

The average number of years of formal education in this group is the smallest in comparison with the other groups and it is $M=9,9$; $s=3,3$. Seniors functioning in this social network type are rarely participants of a religious organization or an organization promoting knowledge. $2 \%$ of seniors of this group are involved in a participation in activities of a religious organization, 0,6 $\%$ of seniors are members of an organization promoting knowledge (e.g. TAU). When asked about a membership in organizations, associations, parties, committees, councils or religious groups $8,6 \%$ of respondents answered positively. These are persons who more frequently than the other two groups answered positively a question regarding their feeling of loneliness. Every fourth senior in this group $(24,7 \%)$ answers positively such a question. In the group 2, in comparison with the other groups, there is the smallest proportion of persons who feel loved and being confided in (87\%).

Type 3 diverse: Group 3 includes 260 persons who are regularly in social contacts with many people. Group 3 makes $3,2 \%$ of all the polled. Persons in this group have around 20 people from their family, 17 good friends and 30 friends whom they are in touch with for social or personal purposes, a few times a year at least. On average they have the biggest number of friends and family members whom they are regularly in touch with in comparison with the other two groups. $71,5 \%$ of seniors in this group have a spouse. The arithmetic average of age in this group is $M=68,2$, the standard deviation is $s=6,4$. This is a group characterized by the biggest proportion of people involved in participation in religious organizations $(8,1 \%)$, and organizations promoting knowledge, for example TAU (2,7\%). When asked about a membership in organizations, associations, parties, committees, councils or religious groups $38,8 \%$ of respondents answered positively. $11,1 \%$ seniors in this group are involved in participation in more than one organization. When asked about the feeling of loneliness $15 \%$ of seniors in this group answered positively. In this group, just as in the group 1, almost everybody feels loved and being confided in $(95,4 \%)$.

On the basis of ANOVA test it can be stated that the three groups differ statistically with regard to age $(\mathrm{F}=40,8, \mathrm{p}<0,01)$. Tukey's HSD test results for unequal samples shows that group 1 and 3 are similar with regard to age, but group 1 and $2(p<0,05)$, and group 2 and $3(p<0,05)$ differ significantly. Group 2 can be described as the group of the oldest ones. There is a significant difference with regard to the years of education $(\mathrm{F}=76,6 ; \mathrm{p}<0,01)$. Group 1 and 3 are similar with regard to that, but group 2 can be described as a group with the lowest level of education. It differs significantly $(p<0,05)$ from group 1 and 3. 
The next step of analysis was to compare three selected groups with regard to the subjective quality of life. Selected three groups of seniors differ statistically significantly with regard to a majority of variables being the indicators of the subjective quality of life (Table 1.). Group 1 and 3 are similar in terms of satisfaction derived from various fields of one's life. Group 2, restricted network, the largest one, the least educated and the oldest one at the same time, is characterized by the lowest level of satisfaction derived from all the fields of life being the subject of analysis. Among fields being analyzed, there is not any field in which their satisfaction would be higher than that of seniors from the other two groups. Group 1 and 3 differ in terms of evaluation of a level of satisfaction from the relation with a circle of friends. Group 3 presents a higher level of satisfaction - diverse (descriptive statistics of a diverse group $\mathrm{M}=2,2 ; \mathrm{s}=0,9$, the family and friend group $\mathrm{M}=2,4, \mathrm{~s}=0,9$, the restricted group $\mathrm{M}=2,7 ; \mathrm{s}=0,9$ ). The next difference regards the level of satisfaction from one's own life achievements. The diverse group expresses the highest level of satisfaction (diverse: $\mathrm{M}=2,5 ; \mathrm{s}=1,0$; family and friend $\mathrm{M}=2,8, \mathrm{~s}=0,9$, restricted: $\mathrm{M}=3,1 ; \mathrm{s}=1,1)$. It is similar in terms of differences when it comes to a range of satisfaction derived from the way of spending leisure time (diverse: $\mathrm{M}=2,4$; $\mathrm{s}=1,0 ;$ family and friend $\mathrm{M}=2,7, \mathrm{~s}=1,0$, restricted: $\mathrm{M}=2,9 ; \mathrm{s}=1,1)$.

\section{Discussion}

The results of research confirmed other authors' observations regarding a 'family' nature of social networks of Polish seniors. In comparison with the research, for example Fiori et al. (2006) or Litwin \& Stoeckel (2013), there can be noticed a lack of a social network type in which a structure consisting of family members does not dominate numerically (for example, nonfamily and friends). Each cluster selected in the group of Polish seniors can be characterized by keeping in touch with family members. Even in the restricted group relatives are those who make the most numerous network structure. As it results from the report by the Centre for Public Opinion Research (OmyłaRudzka, 2012) presenting the results of research carried out on a sample of 266 retired Poles, regarding the ways of spending their leisure time, almost every second woman $(46 \%)$ frequently or occasionally takes care of her grandchildren or great-grandchildren. The proportion regarding men is $39 \%$. There is a tradition in Poland that grandmothers and grandfathers look after their grandchildren when their parents are at work. It is significant when it comes to the well-being of grandchildren. "Relations between grandparents and their grandchildren can be an important element of family relations, and seniors' sacrifice and help can be a really effective form of a social support' (Napora, 2014, p.54). Seniors' contacts with their family may also be indicated by helping their children or a family in running the house. Such a way of spending the time has been declared by $38 \%$ of senior women and $28 \%$ of senior men. A big 
number of the respondents helps also their children and family members with their gainful employment. It is $32 \%$ of women and $24 \%$ of men. It is more likely that in the restricted group there are persons who spend their time in such a way, what results in a lack of time to function in more developed social networks, consisting of members out of the family circle. Functioning in social networks of the restricted type is typical for Polish seniors. Majority of the elderly people in Poland belong to that group. In comparison with the other groups the restricted group can be characterized by the lowest level of satisfaction derived from respondents' health condition. It is another factor that may influence the seniors' lifestyle, in particular - relations with others.

Seniors functioning in the diverse network type are persons with a higher level of formal education in comparison with seniors from the other groups. They are younger in comparison with persons from the restricted group and they evaluate their health condition better. These factors are significant in terms of lifestyle. There is the biggest proportion of persons participating in TAU classes and social organization's activities. These are persons who probably feel comfortably in situations similar to formal learning at school (e.g. TAU). Third Age Universities, also other senior organizations, often aim at seniors' activation, support them in their successful ageing, promote certain behaviours which facilitate the so called healthy lifestyle. Seniors belonging to the diverse group can be said to be highly satisfied from every field of their life. Participation in a social network consisting of such people may enhance a positive, optimistic way of perceiving reality (Kozerska, 2014). Thanks to common experiences, participation in undertakings related to the activity in organizations and interactions with many members of a social network, seniors probably have more opportunities to learn various ways of handling problems from one another; their educational environment is more differentiated than the environment of seniors in the other groups, and it favours learning to a larger extent.

Taking into consideration aspects discussed herein, related to perceiving the quality of life and demographic conditioning, the family and friend group is similar to the diverse group. These are persons with a similar level of education and at the similar age as those in the diverse group. Social networks are not as much developed as in the diverse group, but persons functioning in this network type have numerous relations with relatives and persons out of the family circle. Seniors functioning in the family and friend net do not get involved in various organizations as much as seniors from the diverse group. They maintain relations of another type, more 'modest'. The average evaluation of a level of satisfaction from such contacts is statistically lower than in the diverse group. The evaluation of satisfaction derived from the way of spending leisure time is also lower. The family and friend group keeps in touch mainly with family members. Family members can provide help and support when seniors need it. On the other hand, various family events, family situations that require taking 
care of other family members (e.g. grandchildren, ill family members) may lower a subjective feeling of the life quality within a range of such fields as a level of satisfaction from the way of spending the time or relations with a group of friends. However, the level of general life satisfaction is the same in the diverse and family and friends group. Both groups evaluate own life during the recent days at a similar high level, and they evaluate the level at which they want to live in a similar way. They evaluate their relations with children and spouses at the same high level - there are not statistically significant differences within this field.

The results show a regularity observed many times in the research carried out in various countries: social participation is in relation to the well-being of seniors. The achieved result for example coincides with results by Fiori et al. (2006), according to which seniors functioning in the restricted network got results showing a high intensity of depression symptoms, while the diverse network was characterized by a low level of depression symptoms.

Table 1. Description of a level of satisfaction from selected fields of life of chosen senior groups

\begin{tabular}{|c|c|c|c|c|c|c|c|c|c|}
\hline \multirow{2}{*}{$\begin{array}{c}\text { A field of life for } \\
\text { which a level of } \\
\text { satisfaction was } \\
\text { defined by seniors } \\
\text { (higher values of the } \\
\text { presented scale refer } \\
\text { to a lower level of } \\
\text { satisfaction; scale } \\
\text { from } 1 \text { to } 6 \text { ) }\end{array}$} & \multicolumn{2}{|c|}{$\begin{array}{l}\text { Group } 1 . \\
\text { Family and } \\
\text { friends } \\
2203 \\
\text { persons }\end{array}$} & \multicolumn{2}{|c|}{$\begin{array}{l}\text { Group } 2 . \\
5562 \text { persons } \\
\text { restricted }\end{array}$} & \multicolumn{2}{|c|}{$\begin{array}{l}\text { Group } 3 . \\
260 \text { persons } \\
\text { diverse }\end{array}$} & \multicolumn{2}{|c|}{$\begin{array}{l}\text { Significance } \\
\text { of } \\
\text { differences, } \\
\text { result of } \\
\text { Kruskal- } \\
\text { Wallis test }\end{array}$} & \multirow{2}{*}{$\begin{array}{l}\text { Pairs of } \\
\text { groups which } \\
\text { are } \\
\text { statistically } \\
\text { significantly } \\
\text { different (on } \\
\text { the basis of } \\
\text { the Dunn's } \\
\text { multiple } \\
\text { comparison } \\
\text { test result). } \\
\text { p }<0,05\end{array}$} \\
\hline & M & SSD & SM & SSD & MM & SSD & $\mathrm{H}$ & $\mathrm{p}$ & \\
\hline \begin{tabular}{|l|} 
1. Relations with \\
the closest \\
family members
\end{tabular} & 1,9 & 0,8 & 2,1 & 1,0 & 2,0 & 1,0 & 103,8 & 0,000 & $\begin{array}{l}\text { Group } 1 \text { and } 2 \\
\text { Group } 2 \text { and } 3\end{array}$ \\
\hline $\begin{array}{l}\text { 2. Financial } \\
\text { situation of a } \\
\text { family }\end{array}$ & 3,1 & 1,2 & 3,4 & 1,4 & 3,1 & 1,3 & 85,9 & 0,000 & $\begin{array}{l}\text { Group } 1 \text { and } 2 \\
\text { Group } 2 \text { and } 3\end{array}$ \\
\hline $\begin{array}{l}\text { 3. Relations with a } \\
\text { group of friends }\end{array}$ & 2,4 & 0,9 & 2,7 & 0,9 & 2,2 & 0,9 & 259,4 & 0,000 & $\begin{array}{l}\text { Group } 1 \text { and } 2 \\
\text { Group } 2 \text { and } 3 \\
\text { Group } 1 \text { and } 3\end{array}$ \\
\hline $\begin{array}{l}\text { 4. One's own } \\
\text { health condition }\end{array}$ & 3,5 & 1,3 & 3,7 & 1,3 & 3,4 & 1,3 & 64,8 & 0,000 & $\begin{array}{l}\text { Group } 1 \text { and } 2 \\
\text { Group } 2 \text { and } 3\end{array}$ \\
\hline $\begin{array}{l}\text { 5. One's own life } \\
\text { achievements }\end{array}$ & 2,8 & 0,9 & 3,1 & 1,1 & 2,5 & 1,0 & 177,1 & 0,000 & $\begin{array}{l}\text { Group } 1 \text { and } 2 \\
\text { Group } 2 \text { and } 3 \\
\text { Group } 1 \text { and } 3 \\
\end{array}$ \\
\hline
\end{tabular}




\begin{tabular}{|c|c|c|c|c|c|c|c|c|c|}
\hline $\begin{array}{l}\text { 6. A situation in the } \\
\text { home country }\end{array}$ & 4,5 & 1,2 & 4,5 & 1,2 & 4,3 & 1,4 & 8,3 & 0,02 & --- \\
\hline $\begin{array}{l}\text { 7. } \begin{array}{l}\text { The housing } \\
\text { conditions }\end{array} \\
\end{array}$ & 2,3 & 0,9 & 2,6 & 1,1 & 2,2 & 0,9 & 135,2 & 0,000 & $\begin{array}{l}\text { Group } 1 \text { and } 2 \\
\text { Group } 2 \text { and } 3\end{array}$ \\
\hline $\begin{array}{l}\text { 8. A senior's place } \\
\text { of living }\end{array}$ & 2,2 & 0,8 & 2,4 & 0,9 & 2,2 & 0,9 & 100,5 & 0,000 & $\begin{array}{l}\text { Group } 1 \text { and } 2 \\
\text { Group } 2 \text { and } 3\end{array}$ \\
\hline $\begin{array}{ll}\text { 9. } & \text { Future } \\
\text { perspectives }\end{array}$ & 3,5 & 1,3 & 3,8 & 1,3 & 3,5 & 1,4 & 97,6 & 0,000 & $\begin{array}{l}\text { Group } 1 \text { and } 2 \\
\text { Group } 2 \text { and } 3\end{array}$ \\
\hline 10.Sexual life & 3,2 & 1,2 & 3,5 & 1,3 & 3,1 & 1,3 & 52,3 & 0,000 & $\begin{array}{l}\text { Group } 1 \text { and } 2 \\
\text { Group } 2 \text { and } 3\end{array}$ \\
\hline $\begin{array}{c}\text { 11. One's own } \\
\text { eduaction }\end{array}$ & 2,9 & 1,8 & 3,2 & 1,2 & 2,7 & 1,2 & 116,2 & 0,000 & $\begin{array}{l}\text { Group } 1 \text { and } 2 \\
\text { Group } 2 \text { and } 3 \\
\text { Group } 1 \text { and } 3\end{array}$ \\
\hline $\begin{array}{l}\text { 12. The way of } \\
\text { spending leisure } \\
\text { time }\end{array}$ & 2,7 & 1,0 & 2,9 & 1,1 & 2,4 & 1,0 & 135,1 & 0,000 & $\begin{array}{l}\text { Group } 1 \text { and } 2 \\
\text { Group } 2 \text { and } 3 \\
\text { Group } 1 \text { and } 3 \\
\end{array}$ \\
\hline 13.Children & 1,8 & 0,8 & 2,0 & 0,9 & 1,8 & 0,9 & 68,1 & 0,000 & Group 1 and 2 \\
\hline 14. Marriage & 2,0 & 0,9 & 2,2 & 1,0 & 2,0 & 1,0 & 42,6 & 0,000 & $\begin{array}{l}\text { Group } 1 \text { and } 2 \\
\text { Group } 2 \text { and } 3\end{array}$ \\
\hline $\begin{array}{l}\text { 15. The state of } \\
\text { safety in the } \\
\text { place of living }\end{array}$ & 2,5 & 0,9 & 2,6 & 0,9 & 2,5 & 1,0 & 7,3 & 0,03 & --- \\
\hline $\begin{array}{l}\text { 16. Evaluation of } \\
\text { one's own life } \\
\text { during last days } \\
\text { made by seniors } \\
\text { (scale from } 1 \text { to } \\
4.1-\text { stand for } \\
\text { 'very happy', } 4- \\
\text { 'unhappy') }\end{array}$ & 2,1 & 0,5 & 2,3 & 0,6 & 2,1 & 0,5 & 129,2 & 0,000 & $\begin{array}{l}\text { Group } 1 \text { and } 2 \\
\text { Group } 2 \text { and } 3\end{array}$ \\
\hline
\end{tabular}

Source: own analysis based on: Social Monitoring Council (2013). Social diagnosis: an integrated database. www.diagnoza.com [access 13.02.2014].

Learning (Wenger, 1998) is an essential element of a social participation of an individual. Entering into interactions with other people, realization of common tasks, solving problems and developing confidence require from seniors the constant negotiating and renegotiating of the sense of the world in which they live in, and building one's own identity. This in turn provides some potential to build a social capital that influences the subjective life quality of seniors. The analysis shows that in this respect seniors with higher education are 


\section{SOCIETY. INTEGRATION. EDUCATION. Volume IV}

more privileged. People functioning in poor social networks are characterized by a smaller number of years of formal education. Considering the analysis carried out by Growiec (2009), the social trust is a vital condition needed to form bonds out of the original group. Such bonds can be built by encouraging seniors to cooperate for the benefit of the common good and cross-generational cooperation, thus showing the sense of cooperation to realize the general interest.

\section{References}

Adams, R.G., Blieszner, R. (1995). Aging well with friends and family. American Behavioral Scientist, 39(2), 209-224.

Alesina, A., Giuliano, P. (2010). The power of family. Journal of Economic Growth, 15, 93125.

Cacioppo, J.T., Fowler, J.H., Christakis, N.A. (2009). Alone in the crown: The structure and spread of loneliness in the large social Network. Journal of Personality and Social Psychology, 97, 977-991.

Cheng, S.-T., Lee, C.T.L., Chan, A.C.M., Leung, E.M.F., Lee, J.-J. (2009). Social networks types and subjective well-being in Chinese older adults. Journal of Gerontology: Psychological Sciences, 64, 713-722.

Czapiński, J., Panek, T. (Eds.). (2011). Diagnoza społeczna 2011. Warunki i jakość życia Polaków. Warszawa.

Dominguez, S., Arford, T. (2010). It is all about who you know: Social capital and health in low-income communities. Health Sociology Review, 19, 114-129.

Doubova, S.V., Perez-Cuevas, R., Espinosa-Alarcon, P., Flores-Hernandez, S. (2010). Social networks types and functional dependency in older adults in Mexico. BMC Public Health, 27(10), 104.

Dzięgielewska, M. (2006). Aktywność społeczna i edukacyjna w fazie starości. In: SzaturJaworska, B., Błędowski, P., Dzięgielewska, M. (Eds.), Podstawy gerontologii społecznej (pp. 161-181). Warszawa.

Fiori, K.L., Antonucci, T.C., Cortina, K.S. (2006). Social network typologies and mental health among older adults. Journal of Gerontology, 61B(1), 25-32.

Garcia, E. L., Banegas, J. R., Perez-Regadera, A. G., Cabrera, R., Rodriguez-Artalejo, F. (2005). Social network and health-related quality of life in older adults: A populationbased study in Spain. Quality of Life Research, 14, 511-520.

Grotowska-Leder, J. (2008). Sieci społeczne seniorów mieszkających w rejonach niezurbanizowanych w perspektywie teoretycznej i empirycznej. In: Kowaleski, J.T. , Szukalski, P. (Eds.) Pomyślne starzenie się $w$ perspektywie nauk o pracy i polityce społecznej (pp.129-131). Łódź. Downloaded from: http://dspace.uni.lodz.pl/xmlui/ bitstream/handle/11089/3611/Grotowska-Leder.pdf?sequence=1\&isAllowed=y

Growiec, K. (2009). Związek pomiędzy sieciami społecznymi a zaufaniem społecznym mechanizm wzajemnego wzmacniania?. Psychologia Społeczna, 1-2(10), 55-66.

Illeris, K. (2006). Trzy wymiary uczenia się. Poznawcze, emocjonalne i spoteczne ramy współczesnej teorii uczenia się. Wrocław.

Kargul, J. (2005). Obszary pozaformalnej i nieformalnej edukacji dorostych. Wrocław.

Kääriäinen, J., Lehtonen, H. (2006). The variety of social capital in welfare state regimes - A comparative study of 21 countries. European Societies, 8 (1), 27-57.

Kozerska, A. (2013). Obiektywne środowisko edukacyjne seniorów w Polsce. Edukacja Dorostych, 2(69), 47-58. 
Kozerska, A. (2014). Selected elements of the learning culture at Universities of Third Age in Poland. Journal of Educational Sciences, 1, 31-46.

Litwin, H. (2001). Social network type and morale in old age. The Gerontologist, 41, 516524.

Litwin, H., Stoeckel, K.J. (2013). Confidant networks types and well-being among older Europeans. The Gerontologist, 54(5), 762-772.

Litwin, H., Shiovitz-Ezra, S. (2010). Social Network type and subjective well-being in a national sample of older Americans. The Gerontologist, 51(3), 379-388.

Łukaszewski, W. (1986). Szanse rozwoju osobowości. Warszawa.

Napora, E. (2014). Wsparcie społeczne dziadków, czyli kto i z czego jest zadowolony. Częstochowski Biuletyn Oświatowy, 4, 54-56.

Omyła -Rudzka, M. (2012). Sposoby spędzania czasu na emeryturze. Raport CBOS. Warszawa. Downloaded from http://www.cbos.pl/SPISKOM.POL/ 2012/K 106 12.PDF

Wenger, G.C. (1991). A network typology. From theory to practice. Journal of Aging Studies, 5 (2), 147- 162.

Wenger, E. (1998). Communities of practice: Learning, meaning, and identity. Cambridge. 